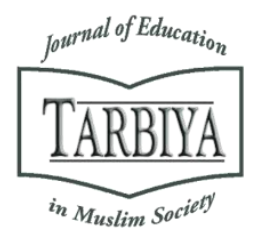

Available online at TARBIYA: Journal of Education in Muslim Society Website:

http://journal.uinjkt.ac.id/index.php/tarbiya

TARBIYA: Journal of Education in Muslim Society, 6(1), 2019, 103-116

\title{
ARABIC LANGUAGE AS THE ICON OF ISLAMIC HIGHER EDUCATION: A STUDY OF THE IMPLEMENTATION OF ARABIC INTENSIVE PROGRAM
}

\author{
Warnis, Hetti Waluati Triana, Remiswal, Martin Kustati, Nelmawarni \\ UIN Imam Bonjol Padang, West Sumatra, Indonesia \\ E-mail: martinkustati@uinib.ac.id
}

Received: $20^{\text {th }}$ April 2019; Revised: $28^{\text {th }}$ May 2019; Accepted: $28^{\text {th }}$ June 2019

\begin{abstract}
Arabic intensive Program is important to improve the quality of foreign language ability for UIN Imam Bonjol students. The planning, implementing and evaluating the process of the Arabic Intensive Program needs to be addressed and improved from various aspects. Thus, the study aims to identify appropriate policies to improve the management of the Intensive Arabic Language program, to develop Arabic language competency standards based on an analysis of the real conditions of the main components and program supporters, and to formulate the standard to improve the quality of Arabic Intensive Programs at UIN Imam Bonjol, Padang. This study used a qualitative approach where the data taken from interviews, documentation and focus group discussion. Data sources are managers, lecturers, and students participating in Arabic Intensive Program. The results of the study showed that the Arabic programs need appropriate policies to overcome the obstacles and problems. The visible problems were in the planning process, especially planning in the learning objectives, materials, and the provision of lecturers; In connection with the implementation of Arabic Intensive programs, there are still constrained by the available facilities and infrastructure, related to evaluation, the results of the study show that comprehensive evaluation needs to be done in relation to the evaluation of inputs, processes, outputs, and impacts to improve the quality of Arabic as an institutional brand in the future.
\end{abstract}

Keywords: Arabic intensive program; planning; application; evaluation

\section{Abstrak}

Program intensif bahasa Arab penting untuk meningkatkan kualitas kemampuan bahasa asing bagi siswa UIN Imam Bonjol. Perencanaan, implementasi dan evaluasi proses Program Intensif Arab perlu ditangani dan ditingkatkan dari berbagai aspek. Dengan demikian, penelitian ini bertujuan untuk mengidentifikasi kebijakan yang tepat untuk meningkatkan manajemen program Bahasa Arab Intensif, untuk mengembangkan standar kompetensi bahasa Arab berdasarkan analisis kondisi nyata dari komponen utama dan pendukung program, dan untuk merumuskan standar untuk meningkatkan kualitas Program Intensif Bahasa Arab di UIN Imam Bonjol, Padang. Penelitian ini menggunakan pendekatan kualitatif dimana data diambil dari wawancara, dokumentasi dan diskusi kelompok terarah. Sumber data adalah pimpinan, dosen, dan mahasiswa yang berpartisipasi dalam Program Intensif Arab. Hasil penelitian menunjukkan bahwa program-program Arab membutuhkan kebijakan yang tepat untuk mengatasi hambatan dan masalah. Masalah yang terlihat dalam proses perencanaan, terutama perencanaan dalam tujuan pembelajaran, bahan, dan penyediaan dosen; Sehubungan dengan pelaksanaan program-program Intensif Bahasa Arab, masih ada kendala oleh fasilitas dan infrastruktur yang tersedia, terkait dengan evaluasi, hasil penelitian menunjukkan bahwa evaluasi komprehensif perlu dilakukan sehubungan dengan evaluasi input, proses, output, dan dampak untuk meningkatkan kualitas bahasa Arab sebagai merek kelembagaan di masa depan.

Kata kunci: Program intensif bahasa Arab; perencanaan; aplikasi; evaluasi

How to Cite: Warnis, Triana, H. W., Remiswal, Kustati, M., Nelmawarni. (2019). Arabic Language as the Icon of Islamic Higher Education: A Study of the Implementation of Arabic Intensive Program. TARBIYA: Journal of Education in Muslim Society, 6(1), 103-116. doi:10.15408/tjems.v6i1. 10910.

Permalink/DOI: http://dx.doi.org/10.15408/tjems.v6i1. 10910 


\section{Introduction}

Arabic Language for Islamic Higher Education (Islamic Universities and Colleges), plays an important role (Alrashidi \& Phan, 2015; Liton, 2012). This vital role can be proven by the application of the Arabic language in exploring, understanding, and analyzing the source materials of Islamic studies. According to Aziz, Ibrahim, Shaker, \& Nor, 2016; Hasan (2009); Versteegh (2001); Wekke (2015), such an important role causes Arabic to become an integral course for the exploration, study, and development of Islamic studies, e.g. jurisprudence, ushul fiqih, interpretation, hadith, Ulumul Quran, and Tauhid. Here, Arabic allows students to achieve their scientific competencies as determined by each department or study program. Indeed, the brand of Islamic universities and colleges lies in their Arabic competences (Onsman, 2011). If the Arabic competences of the alumni are low, the quality of the campus are also considered low (Hillman \& Baydoun, 2018).

Surprisingly, there are some complaints or criticisms arise from Islamic universities and college graduates who are considered to lack adequate independence and lack of language skills so that their competitiveness is lower compared to other institution's alumni. This underdeveloped competitiveness needs to be addressed by providing various "extra skills", e.g., active Arabic skills, including speaking and writing (Hermawan \& Alwasilah, 2011).

Likewise, Al-Batal (2006); Dakwar (2005); Heryanto \& Mandal (2013); Khuwaileh \& Shoumali (2000); Taha-Thomure (2008); Wahab (2016a) revealed the importance of Arabic learning curriculum so that the learning process becomes more qualified, follows the development of scientific (intellectual relevance) and community needs, and get the relatable output in accordance with market demands (social connection) by developing curriculum, learning goals, content, methods, media, interaction, and evaluation of language learning becomes clear, directed, and measurable. Some other researches on Arabic intensive program have been conducted by many scholars. Rosyadi (2018); Sehri (2010) found that Nahu, alqiyasiyyah, and al-istiqrâiyyah become popular methods in Indonesia. The other researches done by (Handriawan, 2015; Hasyim, 2015; Sudiarti, 2015) showed that Arabic learning in Islamic universities was emphasized in reading Arabic texts through an intensive reading based analytical approach. Alqahtani \& Mohammad (2015); Bahri (2014); Kalter-Leibovici et al. (2010); Rhema \& Miliszewska (2010) have conducted research on the Arabic language from historical perspectives. They concluded that the spread of the Arabic language has been in long academic journeys. It is in line with the introduction of Islam all over the world.

Recognizing the importance of Arabic for the attainment of skill competencies, UIN Imam Bonjol Padang has made the Arabic language as a compulsory subject (3 credits) for two semesters, and part of the curriculum in every faculty. However, by relying on Arabic learning or curriculum achievement, it is considered that it has not met the needs of the students. Kyeong, Yun Eun (2012) concluded that the most essential thing in Arabic language curriculum is a curriculum that can integrate comprehensive learning, which incorporates Arabic fushhâ and 'âmiyyah (modern fushha, 'amiyyah of scholars, and dialectical âmiyyah). While Wahab (2016a) considered the importance of curriculum development to pay attention to four things: prospective, procedures, processes and progress. Arabic is also used as the co-curriculum for UIN Imam Bonjol students under the term Arabic Intensive Course introduced in 1998. To facilitate the training and to develop language abilities, the chancellor forms a Language 
Development Unit (UPB) based on the Decree Number In/8/PP.00.9/232/2005 on April 5, 2005. Since then, Arabic learning at UIN Imam Bonjol was conducted by the Language Development Unit (UPB). It means that UPB carries out Arabic learning in two forms, i.e. the curriculum (Regular Arabic Course) and the cocurriculum (Intensive Program).

So far, the implementation of both forms of learning seems to be integrated, both in terms of materials, schedules, and lecturers so that students as participants cannot distinguish and even are not aware of the difference between regular Arabic Course and Intensive Program. Regular Arabic language learning has been separated from the Intensive Arabic Language program in the even semester of 2016/2017.

Based on the preliminary study of Arabic Intensive Program in the last three years (2014/2015, 2016/2017, and 2018/2019) showed that Arabic Intensive Program still has not strengthened students' Arabic abilities as the "brand" of UIN Imam Bonjol. It means that the Intensive program has not shown optimal results even though Arabic has been taught intensively, also, to be in a compulsory curriculum in all faculties. The ineffectiveness of the Arabic Intensive Program is reflected in the commentaries of lecturers in various scientific fields, the comprehensive examination examiners, and the Arabic lecturers themselves. Reality shows that most students no longer take Arabic books as the primary reference because they cannot read the texts. Some lecturers do not take resources in Arabic because it would make the lecturing process to the other form of the translation process. The reality also shows that most students find it difficult and frightening to take a comprehensive exam in Arabic.

However, the reality is very different from the evaluation results of the Arabic Intensive Program which shows that only a small percentage of students do not master Arabic.
Based on the observation at the Language Program at State Islamic University Imam Bonjol, It was found that the evaluation results for the even semester of 2014/2015 showed that out of 1.503 students as the program participants, 652 people $(43.4 \%)$ got A, 613 people $(40.8 \%)$ got B, 214 people $(14.2 \%)$ students get $\mathrm{C}$ grade and only 24 people $(1.6 \%)$ students get $\mathrm{D}$ grade, (UPB Announcement at the beginning of the odd semester 2016/2017). The data suggest that, quantitatively, $84.2 \%$ of UIN Imam Bonjol students already master Arabic. It means that the program has achieved its target in accordance with established competency standards. It can be concluded that the average Arabic language ability of students is adequate.

The real conditions above indicate that Arabic Intensive Program is still problematic even though it has been managed by the UPB as a unique institution. The uncertain of the program is more visible when each of the main components of the implementation of the Arabic Intensive Program is carefully examined.

The determination of Arabic Intensive classes is carried out in stages based on the results of the placement test, i.e., class A (ones who able to read the text); class $\mathrm{B}$ (ones who mastering qawaid); and class $\mathrm{C}$ (ones who only master vocabulary). Although placement tests are expected to map student competencies, they are not implemented correctly, which is marked by the presence of several students who were from boarding schools study in classes with lower competency standards. Conversely, some students who have a general background (regular secondary school and vocational secondary school) education in classes with higher competence: B and A classes.

The problems of the Arabic Intensive Program could also be observed through data from lecturers and students. Compared with the number of students, the numbers of lecturers are 
not comparable to the number of students who take Arabic Intensive Programs. The same condition also happened to the facilities and infrastructure. The classrooms are not enough to accommodate the number of participants of the Arabic Intensive Program.

Although lecturers and facilities are not comparable to the number of students, the achievement standards that have been targeted by the program have not changed in the last three academic years. Arabic Intensive Program could be labeled as ambiguous, e.g., the purposes of the students to get language skills and knowledge. The same phenomenon has also been raised by (Wahab, 2016b) who said that the orientation of Arabic programs in educational institutions seems to be ambiguous and half-way between proficiency orientation and scientific orientation. Both directions need to be mastered by students. However, Arabic Intensive Program needs to focus on one thing so that the learning objectives are more directed.

The statement above shows that the implementation of the Arabic Intensive program is still problematic. This problem will undoubtedly have an impact on the quality of UIN Imam Bonjol graduates so that the competitiveness of the graduates is lower compared to other Islamic Universities and Colleges alumni. This statement is in line with the view of Albulayhi (2018) which emphasizes that the lower competitiveness of the students needs to be addressed by providing various "extra skills", especially in Arabic skills. Indeed, critical thinking and dynamic steps required to overcome these problems.

There are no specific reports on the appropriate standards of the management, quality of the Intensive Arabic Language program, and the development of students' competency. Thus, the current study identifies proper policies to improve the management of the future Intensive Arabic Language program, to develop Arabic language competency standards based on an analysis of the real conditions of the main components and program supporters, and to formulate the rule to improve the quality of Arabic Intensive Programs at UIN Imam Bonjol, Padang. In short, these data should be acquired to determine the progress that will be achieved by the Arabic learners by the end of the program

\section{Method}

Qualitative research was used where the data were collected through some informants i.e. officials, lecturers, and students participating in Arabic Intensive Program in UIN Imam Bonjol. By using a snowball sampling technique, the informants of this research amounted to 88 people, consisting of 11 lecturers, 72 students/participants, and 3 officials of the Arabic Intensive Program. Apart from the informants, the research data was also collected from UPB documents, including the Chancellor's Decree, syllabus, placement test question sheets, examination question sheets, textbooks volumes 1, 2, and 3, schedules, students' scores, announcements, and notes from the meetings. In collecting data, researchers used tape recorders as recording devices and data cards for field notes. This study also used interviews and FGD (Focus Group Discussion). FGD was carried out to verify and validate documentation data and interviews with relevant parties, such as the chief and officials of Arabic Intensive Program, Arabic lecturers, and students participating in the Arabic Intensive Program. Data analysis was done qualitatively to describe and explain in detail to see the implementation of the Arabic Intensive Program, especially in regard to the planning, implementation, and evaluation process. 


\section{Results and Discussion}

\section{The Characteristic of Language Development Unit (UPB)}

As a technical support element, UPB has 7 functions: 1) arranging and implementing work programs and plans for UPB activities; 2) implementing and developing a learning atmosphere and learning process; 3) managing students' registration and her-registration; 4) fostering lecturers in language development; 5) planning and managing cooperation with all implementing elements inside and outside the campus; 6) establishing lecturers in the Language Development Unit; and 7) submitting a report to the Chancellor.

In the early period (2005-2006), the organizational structure of UPB consisted of the chief, secretary, Indonesian Language Coordinator, Arabic Language Coordinator, English Language Coordinator, and lecturers. Each element has its duties and functions to support the task of the head of the unit in leading, implementing, and developing language learning at UIN Imam Bonjol (former: Islamic Institute). Based on those functions, it can be seen that the establishment of UPB is intended as an effort to improve the language competences of UIN Imam Bonjol human resources. During this period, there were no programs, activities, and achievements obtained. In other words, even though the function of UPB has been formulated, also stipulated in the Rector's Decree, UPB as an institution had not carried out its organizational capacity. However, It does not mean that there are no activities related to language learning in this period.

During the developing period (2007-2010), programs and activities managed by UPB have included activities in teaching and learning processes. The Chancellor's Decree number has proved it In.05/KP.00.3/1374/2007 This stipulates the teaching team of Arabic Intensive of the first semester in the academic year of 2008/2009. UPB programs and activities during this period can also be proven through the results of the board meeting on March 12, 2008, and a meeting with Arabic and English lecturers on March 18 and 25, 2008. Based on the result of the two meetings, the Chancellor of IAIN Imam Bonjol (before converting to UIN Imam Bonjol Padang) established the Arabic and English Language Learning and Developmental Program Team of IAIN Imam Bonjol Islamic in 2008 through decree number 16 of 2008 on April 7, 2008.

Between 2011 and 2014, the name of UPB was re-used, as stated in Rector's Decree on January 2, 2012, concerning the Chief and Secretary of the Language Development Unit for the period 2011-2015. However, since 2013, by the Minister of Religion Regulation number 19 of 2013 concerning the IAIN Imam Bonjol Organization and Work Procedure, the name UPB was changed to the Technical Implementation Unit of the Language Development Center. Although it has changed its name, program, activities, and achievements in this period were not only focused on the Arabic Intensive Program but also included English Intensive Program.

Since 2005 there are three names of institutions that are used to refer to the implementing agencies of the Arabic Intensive Program. The three names were still in use up to the last three years through UPB has consistently used the name of the Language Development Center. Inconsistencies in documents are more because of the administrative aspects while the legal basis for the implementation of UPB programs and activities is the decree of the Rector of IAIN Imam Bonjol. The Decree is issued annually and is valid in only 1 year according to the budget period.

UPB already has its own building which is used for the main office of the Arabic Intensive 
Program. In addition to offices, the building is also used for meeting rooms, laboratories, and study rooms. Nevertheless, the UPB building cannot accommodate all activities of the Arabic Intensive Program because of the limited amount of study space. Thus, UPB collaborates with faculties in the framework of implementing the UPB program related to the placement test and learning process.

\section{Planning Process of Arabic Intensive Program}

The planning process of the Arabic Intensive Program is intended as a preparation for ways and tips for implementing activities that cover all components of the program. Considering that Arabic Intensive Program focuses on learning, the program planning process, in this case, refers to efforts to prepare learning components both for face-to-face activities, structured tasks, and independent tasks.

The planning process of a program starts with setting targets or achievement standards as a reference for the implementation of a program and becomes a benchmark for the success of a program. Standard Achievement of Arabic Intensive Program for UIN Imam Bonjol students is not the same. The achievement standard is divided into student learning classes, which also show the level of achievement. Because there are 3 Intensive Arabic levels, i.e. A, $\mathrm{B}$, and $\mathrm{C}$, the determination of the achievements of the Arabic Intensive Program is also based on each level.

After looking at the syllabus of the three levels, it can be emphasized that: First, the standard achievement program for Arabic 1 and 2 of each class is out of sync so it does not indicate the level or level of achievement that must be achieved in this series. It illustrates that the determination of the standard achievement of Arabic Intensive Program listed in the syllabus, is not formulated and reviewed by the
UPB team in accordance with the Arabic language needs of the students of UIN Imam Bonjol. The syllabus is prepared only to meet the requests of the academics. In addition, the process of preparing the syllabus was not followed by any workshop but only arranged by several lecturers. This condition has caused the achievement of the standards of Arabic Intensive Program 1, and 2 do not implement the lecturing series e.g. standard achievement of Arabic Intensive 2 was lower than Standard achievement of Arabic Intensive 1. Problems that arise in the syllabus/curriculum are caused by the preparation process of syllabus/curriculum was not begin from the needs, but rather compiled based on books/teaching materials that have been prepared in advance.

To position and determine the direction of Arabic Education Program curriculum development in the future, according to (Wahab, 2016b) there are four orientations of Arabic education that must be considered: First, religious orientation, e.g. learning Arabic for the purpose of understanding and Implementing Islam (fahm almaqrû́). This orientation is seen in listening and reading skills, as well as speaking and writing; Second, academic orientation, which is learning Arabic for the purpose of understanding Arabic itself and the extra skill in translation: Third, professional/practical and pragmatic orientation, e.g. learning Arabic for professional purposes and interests: and Fourth, ideological and economic orientation.

The curriculum of the Arabic Intensive Program was formulated based on Li Ghairi AnNathiqiina Biha's Ta'lim Al-Arabiyah book published by Ummul Qura University, Mecca, in 1984. This book was compiled by Abdullah Sulaiman Al-Jarbu', Tammam Hasan Umar, Mahmud Kamil An-Naqah, Abdullah Abdul Karim Al-Abbadi, Ali Muhammad AL-Fiqi, and Rusdu Ahmad Thu'aimah. Here the teaching material for Arabic Intensive Program is 
formulated based on the book and is used as the references or textbook for Arabic Intensive Program in UIN Imam Bonjol.

There are three volumes of the books used as the teaching materials. Volume 1 is the teaching material for level $\mathrm{C}$, volume 2 is the teaching material for level $\mathrm{B}$, and volume 3 is the teaching material for level A. In general, the three books have the same goal: teaching Arabic skills to non-Arabic speakers. The skills in question are listening skills (maharah al-istima), speaking skills (maharah al-kalam), reading skills (maharah al-qira'ah), and writing skills (maharah al-kitabah). The materials related to various skills are contained in all three textbooks, but at different levels. This is because the learning process offered by this book is a gradual learning process.

Volume 1 contains basic Arabic and its orientation is to master Arabic vocabulary. Volume 2 explains in a more detail concept begins with the method and concept of Imla'. Volume 3 presents the material in the form of literary works. Volume 3 is a very complex book. It is oriented towards reading competence.

However, the textbook was never revised or replaced considering differed participants and allocated periods from time to time. Thus, it is clear that the planning of the Arabic Intensive program is not processed in accordance with the real conditions in UIN Imam Bonjol, in both numbers and competences of the program participants.

The standard achievement and the three materials above are in line with the placement test program which is basically conducted to obtain an overview of the basic abilities of prospective program participants, to place which level is appropriate for each students' abilities. The backgrounds of the participants of the Arabic Intensive Program are very diverse. This diversity is not only in terms of the area of residence and social status, but also educational background (Islamic boarding school, Islamic Secondary School, regular secondary school, and/or vocational secondary school) which affected the learning process. Indeed, UPB already prepares three levels.

Level A is intended for students who have Arabic language skills that are good enough or more. Level B is intended for students whose Arabic language skills are not good enough (not yet able to speak Arabic and not yet able to read Arabic text). Level $\mathrm{C}$ is intended for students who have no Arabic language skills at all.

Based on the purposes above, UPB conducts a placement test for program participants. Placement tests are required for all program participants. The placement test question sheets are designed in such a way that the test results are expected to illustrate the ability of prospective participants in the Arabic Intensive Program. Based on the results of the placement test, participants are classified into levels A, B, or C.

However, prospective program participants have their techniques for choosing their levels by manipulating the placement test e.g. by not filling in the answers on the question sheets or by filling out the answer sheets in a limited manner so that they can be placed in the lower level. A similar technique was applied by 56 of 72 student informants. This finding indicates that the placement test was not an effective way of identifying and measuring the language skills of the prospective participants in the Arabic Intensive Program.

Regarding lecturers, the data shows that the number of lecturers in the Arabic Intensive Program is 33 permanent lecturers and 15 nonpermanent lecturers, while the number of students in $2014 / 2015$ is 2,144 and 2.500 in $2017 / 2018$. The comparison of the two data is very irrational. Arabic Intensive lecturers were 
recruited from all Arabic lecturers in every faculty of UIN Imam Bonjol. While the permanent recruitment of lecturers is carried out by UPB is in accordance with its duties and functions. Lecturers' recruitment is managed by following procedures and meeting the criteria. The qualifications of the lecturers have become more urgent to achieve the targets. Nevertheless, there were no SOP or criteria for Arabic Intensive lecturer recruitment so far.

Based on the UPB document, it is known that the available classrooms are at its minimum capacity, and can even be said to be inadequate in quantity. Inadequate facilities and infrastructure indicate that the amount of classrooms does not match up with a number of participants. The data shows that in 2014/2015, there were only 30 classrooms available, while the compulsory classrooms are at least 70 classrooms. The unavailability of the classrooms had caused the under-implementation of the Arabic Intensive Program compared to the previous academic year.

Based on the analysis of the planning process, it can be emphasized that Arabic Intensive Program does not begin with the correct approach. In fact, it can be said that the program has not carefully planned that there was no agreement among the managerial components. Reality shows the different perspectives from the views of Couller and Nggili (2013) who precisely insist that a program must begin with planning. In other words, the planning process of the Arabic Intensive Program by UPB did not follow the theory of management so that the directions and objectives of the program were unclear.

\section{The Application of Arabic Intensive Program}

The next presentation is the findings and analysis of research data related to the process of the implementation of the Arabic Intensive Program. In the process of implementing Arabic
Intensive Program the results and analysis of the research data are divided into: 1 ) the process of managing Arabic Intensive Program; 2) the lecturing process of Arabic Intensive Program; 3) the strengthening of the Human Resources of Arabic Intensive Program; 4) the mechanism of financial use of Arabic Intensive Program; 5) the lecturing schedule of Arabic Intensive Program; 6) the supporting facilities for Arabic Intensive Program; and 7) the evaluation of Arabic Intensive Program. For more details, the findings and analysis of research data related to the process of implementing the Arabic Intensive Program can be explained as follows.

The process of managing the Arabic Intensive Program is done through meetings held by UPB with Arabic lecturers. The structural and scheduled meetings related to Arabic Intensive Program have not yet existed, but every problem associated with the implementation of the Arabic Intensive Program is followed up by holding meetings with lecturers, board members, and the officials of the Arabic Intensive Program.

In the lecturing process of the Arabic Intensive Program, students classify lecturers into four categories i.e. senior lecturers with professional qualifications, ordinary senior lecturers, and junior lecturers with excellent competence and regular junior lecturers. This category also distinguishes the level of competency of lecturers as international information for the lectures.

In connection with the description above, if it is associated with the number of lectures of the Arabic Intensive Program is very inadequate. This condition was evidenced by 33 permanent lecturers in Arabic, while there were 15 permanent lecturers. The numbers and the qualifications (academic degree) of the permanent and non-permanent lecturers of Arabic Intensive Program are as follows: 
Table 1. The Qualification of the Lectures of Arabic Intensive Program

\begin{tabular}{llllll}
\hline Status & \multicolumn{3}{l}{ Academic Qualification } & Total \\
& $\begin{array}{l}\text { Profe } \\
\text { ssor }\end{array}$ & $\begin{array}{l}\text { Doct } \\
\text { or }\end{array}$ & $\begin{array}{l}\text { Magist } \\
\text { er }\end{array}$ & $\begin{array}{l}\text { Bachel } \\
\text { or }\end{array}$ & \\
\hline $\begin{array}{l}\text { Permanent } \\
\text { Lectures }\end{array}$ & 1 & 9 & 20 & 3 & 33 \\
$\begin{array}{l}\text { Non- } \\
\text { Permanent }\end{array}$ & - & - & 15 & - & 15 \\
Lectures & & & & & \\
\hline Total & 1 & 9 & 35 & 3 & 48 \\
\hline Source: UPB Document & & & &
\end{tabular}

In line with human resources, the facilities available were also inadequate. Indeed, UPB only uses the available classrooms or by emptying classrooms available in all faculties of UIN Imam Bonjol. Related to this situation, the scheduling process carried out by UPB is based on the availability of classes, in addition to the similarity of the implementation time. The scheduling process is carried out by taking into account the various components of the program included the curriculum, teaching staff, facilities, and program participants so that there are no clashes in the implementation of the program.

Based on the conditions above, UPB sets the class schedule from 2:00 p.m. to 3:40 p.m. for session one and 4:00 p.m. to 5:40 p.m. for session 2. The program was held from Monday to Friday provided that each participant participates in the program twice a week, while the lecturers are required two times a week and for certain lecturers had to carry the program more than two times a week

In relation to lecturing material, following the contents of textbooks which are used as learning resources, there was no variation in teaching methods and material. Lecturers discuss more in theory, not in the application domain. Lecturers lured students to be actively involved by asking questions and giving them the opportunities to ask questions.

Related to the supporting facilities, UPB has not utilized such kinds of media e.g. tape recorder, slideshow, and projector. It is very unfortunate for the students because there is some material such as istima' or listening which requires technology media to train students' skills in listening to Arabic requires supporting technology. However, in the discussion of the material the lecturers never used media e.g. by providing tape recorders, videos, and/or loudspeakers in practice.

There are three types of evaluation on Arabic Intensive Program: 1) daily evaluations that contribute 20 percent to the final score; 2 ) midterm evaluation that contributes 30 percent to the final score, and 3) final semester evaluation that contributes 50 percent to the final score.

Noting the scores of the students from the UPB document, it is known that the scores achieved by the students are based on the final semester examinations, the average score is considered as good (A and B) and only a small percentage get $\mathrm{C}$. The examination question sheets are taken from the book i.e. volume 1, volume 2 , and volume 3 . It means that the final examination question sheets given to the students differ between level A, level B, and level C. This condition made the obtained scores of the students to be more prominent because the questions given are questions that have been discussed on the textbook in accordance with the students' group level.

The following table is the final scores obtained by the students from the results of the last semester examinations on level A, level B, and level C: 
Table 2. Arabic Intensive Program 2018/2019 Students' Scores list

\begin{tabular}{|c|c|c|c|}
\hline Level & Scores & Semester 1 & Semester 2 \\
\hline \multirow{6}{*}{ A } & $\mathrm{A}$ & 32 & 15 \\
\hline & B & 14 & 4 \\
\hline & $\mathrm{C}$ & 6 & - \\
\hline & $\mathrm{D}$ & - & - \\
\hline & $E$ & - & - \\
\hline & Incomplete & 6 & 39 \\
\hline \multirow[t]{2}{*}{ Total } & & 58 & 58 \\
\hline & $\bar{A}$ & 118 & 106 \\
\hline \multirow{5}{*}{ B } & B & 57 & 41 \\
\hline & $\mathrm{C}$ & 14 & 6 \\
\hline & $\mathrm{D}$ & 4 & 2 \\
\hline & $\mathrm{E}$ & 2 & - \\
\hline & Incomplete & 12 & 52 \\
\hline \multicolumn{2}{|l|}{ Total } & 207 & 207 \\
\hline \multirow{6}{*}{ C } & $\bar{A}$ & 864 & 581 \\
\hline & B & 496 & 844 \\
\hline & $\mathrm{C}$ & 238 & 202 \\
\hline & $\mathrm{D}$ & 23 & 28 \\
\hline & $\mathrm{E}$ & - & 3 \\
\hline & Incomplete & 119 & 82 \\
\hline Total & & 1740 & 1740 \\
\hline
\end{tabular}

The evaluation results as a whole showed that out of 2.005 students in the first semester, about 1.581 people $(78.85 \%)$ got $\mathrm{A}$ and $\mathrm{B}$ grades, and in the second semester, about 1.591 people $(79.35 \%)$ got $A$ and $B$. These mean that learning Arabic Intensive is effective and the participants have competencies in accordance with the learning objectives.

However, the results of the learning evaluation cannot be used as an indicator of success because the learning outcomes cannot be used as a standard for the level of Arabic proficiency of the students of UIN Imam Bonjol. The results of the analysis showed that the Arabic abilities of the students do not support their knowledge.

\section{Evaluation Process of Arabic Intensive Program}

Program evaluation according to (R. Lavinghouze, Webb Price, \& Smith, 2007; S. R. Lavinghouze, Snyder, \& Rieker, 2014) is seized to 1) provide accountability for activities to the community, stakeholders, and donor agencies; 2 ) help determine the goals that have been determined in planning; 3) improve the implementation program; 4) contribute to scientific understanding of the results of a program; 5) increase awareness and support for the community; and 6) inform policy. About this research, the evaluation process of the Arabic Intensive Program in UIN Imam Bonjol is an evaluation of input, application of the process, evaluation of output, and evaluation of the impact both for the impact of students and the impact on institutions.

\section{The Evaluation of Arabic Intensive Program Input}

According to (Posavac, 2015; Wiyoko, 2016), input evaluation helps regulate decisions, determine available sources, what alternatives should be taken, what plans and strategies should do to achieve goals, and how the correct working procedures to achieve them. The components of input evaluation include: 1) Human resources, 2) Supporting facilities and equipment, 3) Funds and 4) Various procedures and rules needed.

Evaluations related to student input have never been done. This can be seen from the placement test questions conducted in the same three years, both the model and the form of the questions that were used as test questions. The results of the evaluation test show that students from Islamic boarding schools should be in level A but in reality there are many boarding schools and Madrasah graduates who are not in level A, instead they prefer to be in level C. This condition shows that the placement test results are not as expected.

Student placement should be based on the results of the reinforcement test in accordance with the ability of students, e.g. level A students who have the ability to read 
text, level B students who master the rules, and level $\mathrm{C}$ students who master vocabulary.

The discrepancy between the results of the placement test and student placement level has occurred since the last few years. This is because the standard of assessment of the students is applied equally to levels A, B, and C. Students who come from boarding schools and Madrasas who are supposed to be at level $\mathrm{A}$ or $\mathrm{B}$, prefer to be in level $\mathrm{C}$ by simply dropping two placement test questions tested. So from the low placement test, the results of their test would place them into level $\mathrm{C}$ when their capabilities are in level A or B.

The Evaluation of the Application Process of Arabic Intensive Program

The evaluation of the process is basically done to find out how far the plan has been implemented and what components need to be improved. According to (Apriandi \& Setyansah, 2017; Divayana \& Sanjaya, 2017), the evaluation of the process in the CIPP model refers to "what" activities are held in the program, "who" are the persons appointed as the persons in charge of the program, "when" will the activity be completed. Indeed, the evaluation of the process is directed at how far the activities would do and how far the program has been done in accordance with the plan

Evaluation related to the process is more focused on the implementation of the program, whether according to plan, starting from the planning, organizing and implementation stages. Until now there has been no evaluation of the process of the Arabic Intensive Program. It is proven by the activities done in which activities were done in the previous year. If the planning, organizing, and implementation are evaluated, of course, the implementation of Arabic Intensive Programs can be better than the previous year, and it would change the process and results of teaching and learning in the upcoming year.

\section{The Evaluation of Arabic Intensive Program Output}

The evaluation at this stage is an evaluation done when the program has been completed. There has been no evaluation of student achievement standards related to the teaching materials and the learning methods used.

Students' competencies after attending Arabic Intensive Programs taken from the students' learning outcomes have been marked with high ability according to the scores obtained by the dominant students of level A and B. However, if it is associated with students' Arabic language skills in the relevant fields of science, the improvements have not been adequately improved. The results of the study showed that students have not been able to understand the book sources related to their fields of science in Arabic. It means that Arabic Intensive Program they have participated in for two semesters has not been able to help them in increasing their Arabic abilities in understanding books in Arabic related to their majors.

\section{Evaluation of the impact of Arabic Intensive Program}

Assessment of the effects is an evaluation relating to the Intensive Arabic Language program which includes the effects arising from the program implemented (Hanafi, 2014; Rozarie \& Indonesia, 2017). The main objectives, in general, can be divided into two types, i.e. to measure output (impact on students) and 
to measure the impact produced (impact on the institutions).

If you discuss the impact of output, there are two things that can be categorized as output impacts. They are the impact in terms of material and the impact in terms of motivation. The majority of informants interviewed stated that there was no significant impact on the addition of material. Some students mentioned that they had already studied Arabic Intensive material at their previous school (for boarding schools and madrasas graduates) and some others mentioned that they were indeed unable to understand the material presented by the lecturer (Yulia, 2013). In terms of motivation, some students feel that there is an additional motivation to learn Arabic more actively. Most likely this is the impact of the motivations given by lecturers through their stories and experiences.

Furthermore, the impact on institutions, Arabic Intensive Program so far has not been reflected in improving institutional accreditation and has not been able to become the icon of UIN Imam Bonjol. It is due to the absence of evaluations that have been carried out on the clarity of learning objectives and the achievement standard of the Intensive Arabic Language program that students must take.

\section{Conclusion}

The Arabic Intensive Program implemented by the Language Development Unit (UPB) is focused on efforts to improve the Arabic language skills of the new students of UIN Imam Bonjol. To achieve these objectives, the optimum efforts are needed, especially by UPB officials and lecturers.
Although program managers and implementers have tried optimally, the reality shows that the implementation of the Arabic Intensive Program is still having some problems. The problems are more due to the optimality of the program planning process, including the determination of standards performance, teaching staff, participants, scheduling, funding, facilities, and infrastructure that facilitate the program. The program planning process has not been optimally implicated in the process of implementing and evaluating the Arabic Intensive Program.

Considering that Arabic is a foreign language that is also a brand of Islamic universities and colleges, Arabic Intensive Program is important to improve the quality of UIN Imam Bonjol. It means that Arabic Intensive Program is still needed and needs to be maintained. However, the planning, implementing and evaluating the process of the Arabic Intensive Program needs to be addressed and improved from various aspects.

\section{References}

Al-Batal, M. (2006). Playing with words: Teaching vocabulary in the Arabic curriculum. Handbook Arabic Language Teaching Professionals in the 21st Century, 331-340.

Albulayhi, A. (2018). Teachers' Attitudes Regarding the Inclusion of Students with Visual Impairment in Saudi Arabian Public Schools (PhD Thesis). Saint Louis University.

Alqahtani, M., \& Mohammad, H. (2015). Mobile applications' impact on student performance and satisfaction. Turkish Online Journal of Educational Technology-TOJET, 14(4), 102-112. 
Alrashidi, O., \& Phan, H. (2015). Education Context and English Teaching and Learning in the Kingdom of Saudi Arabia: An Overview. English Language Teaching, 8(5), 33-44.

Apriandi, D., \& Setyansah, R. K. (2017). Penerapan Media Simulasi Matlab Berbasis Interactive Conceptual untuk Meningkatan Pemahaman Konsep Mahasiswa. AKSIOMA: Jurnal Program Studi Pendidikan Matematika, 6(2), 189 197.

Aziz, A. A., Ibrahim, M. A., Shaker, M. H., \& Nor, A. M. (2016). Teaching Technique of Islamic Studies in Higher Learning Institutions for Non-Arabic Speakers: Experience of Faculty of Quranic and Sunnah Studies and Tamhidi Centre, Universiti Sains Islam Malaysia. Universal Journal of Educational Research, 4(4), 755-760.

Bahri, R. (2014). Pembelajaran Bahasa Arab sebagai Bahasa Asing: Sebuah Tinjauan Historis. Jurnal Tadbir, 2(1), 1-6.

Dakwar, R. K. (2005). Children's attitudes towards the diglossic situation in Arabic and its impact on learning. Languages, Communities, and Education, 3, 75-86.

Divayana, D. G. H., \& Sanjaya, D. B. (2017). Mobile phone-based CIPP evaluation model in evaluating the use of blended learning at school in Bali. International Journal of Interactive Mobile Technologies (IJIM), 11(4), 149-159.

Hanafi, M. (2014). Manajemen risiko.

Handriawan, D. (2015). Mempertegas Kembali Arah Pembelajaran Bahasa Arab: Perspektif Budaya terhadap Tradisi Belajar Bahasa Arab di Indonesia" dalam AlMahāra. Jurnal Al-Mahara, 1(1), 43-64.
Hasan, N. (2009). Islamizing formal education: Integrated Islamic school and a new trend in formal education institution in Indonesia.

Hasyim, M. (2015). Andragogi Dalam Pembelajaran Bahasa Arab. Arabiyat: Jurnal Pendidikan Bahasa Arab Dan Kebahasaaraban, 2(1), 31-42.

Hermawan, A., \& Alwasilah, C. (2011). Metodologi pembelajaran bahasa Arab. PT Remaja Rosdakarya.

Heryanto, A., \& Mandal, S. K. (2013). Challenges to authoritarianism in Indonesia and Malaysia. In Challenging Authoritarian Rule-SEA NIP (pp. 11-33). Routledge.

Hillman, J. R., \& Baydoun, E. (2018). The future of universities in the Arab region: A review. In Universities in Arab countries: An urgent need for change (pp. 1-53). Springer.

Kalter-Leibovici, O., Younis-Zeidan, N., Atamna, A., Lubin, F., Alpert, G., Chetrit, A., ... Freedman, L. S. (2010). Lifestyle intervention in obese Arab women: A randomized controlled trial. Archives of Internal Medicine, 170(11), 970-976.

Khuwaileh, A. A., \& Shoumali, A. A. (2000). Writing errors: A study of the writing ability of Arab learners of academic English and Arabic at university. Language Culture and Curriculum, 13(2), 174-183.

Kyeong, Yun Eun. (2012). Afdhal Manhaj Ta'lim al-Lughah al-'Arabiyyah li Ghair anNathiqina biha min Wijhat Nazhar 'Ilm al-Lughah al-Ijtima’i. Edisi 201, 2012.

Lavinghouze, R., Webb Price, A., \& Smith, K.A. (2007). The program success story: A valuable tool for program evaluation. Health Promotion Practice, 8(4), 323331. 
Lavinghouze, S. R., Snyder, K., \& Rieker, P. P. (2014). The component model of infrastructure: A practical approach to understanding public health program infrastructure. American Journal of Public Health, 104(8), e14-e24.

Liton, H. A. (2012). Developing EFL teaching and learning practices in Saudi colleges: A review. Online Submission, 5(2), 129152.

Onsman, A. (2011). It is better to light a candle than to ban the darkness: Government led academic development in Saudi Arabian universities. Higher Education, 62(4), 519-532.

Posavac, E. J. (2015). Program evaluation: Methods and case studies. Routledge.

Rhema, A., \& Miliszewska, I. (2010). Towards e-learning in higher education in Libya. Issues in Informing Science and Information Technology, 7(1), 423-437.

Rozarie, C. R. D., \& Indonesia, J. T.-N. K. R. (2017). Manajemen sumber daya manusia.

Sudiarti, S. (2015). Peningkatan Keterampilan Membaca Teks Arab Gundul melalui Aktifitas Membaca Intensif Berbasis Gramatikal: Studi Kasus Mahasiswa Bahasa dan Sastra Arab IAIN STS Jambi. FENOMENA, 7(1), 29-42.
Taha-Thomure, H. (2008). The status of Arabic language teaching today. Education, Business and Society: Contemporary Middle Eastern Issues.

Versteegh, K. (2001). Linguistic contacts between Arabic and other languages. Arabica, 48(4), 470-508.

Wahab, M. A. (2016a). Standarisasi kurikulum pendidikan bahasa Arab di perguruan tinggi keagamaan Islam negeri. Arabiyat: Jurnal Pendidikan Bahasa Arab Dan Kebahasaaraban, 3(1), 32-51.

Wahab, M. A. (2016b). Tantangan dan prospek pendidikan Bahasa Arab di Indonesia.

Wekke, I. S. (2015). Arabic teaching and learning: A model from Indonesian muslim minority. Procedia-Social and Behavioral Sciences, 191, 286-290.

Wiyoko, E. P. (2016). Evaluasi Program Pembelajaran Panduan Praktis bagi Pendidik dan Calon Pendidik. Yogyakarta: Pustaka Pelajar.

Yulia, Y. (2013). Teaching Challenges In Indonesia: Motivating Students And Teachers'classroom Language. Indonesian Journal of Applied Linguistics, 3(1), 1-16. 